\title{
Determinants of climate variability adaptation and mitigation strategies harnessed by smallholder maize farmers in Sebayeng village, Limpopo Province, South Africa
}

\author{
${ }^{1}$ Mangwane, Q. and ${ }^{2}$ Oluwatayo, I.B. \\ ${ }^{1}$ Department of Agricultural Economics and Animal Production, University of Limpopo, Sovenga 0727, \\ South Africa \\ ${ }^{2}$ Department of Agricultural Economics and Agribusiness, University of Venda, Thohoyandou, 0950, South \\ Africa
}

\author{
Article history: \\ Received: 11 July 2020 \\ Received in revised form: 13 \\ August 2020 \\ Accepted: 14 September 2020 \\ Available Online: 25 April \\ 2021
}

\section{Keywords:}

Adaptation,

Climate variability,

Determinants,

Mitigation,

South Africa

DOI:

https://doi.org/10.26656/fr.2017.5(2).344

\begin{abstract}
Climate variability is an issue of serious concern especially in a water-scarce country like South Africa. This is because a sizeable number of households in the country reside in the rural area where rain-fed agriculture is the main source of livelihood for the people. This study, therefore, examined factors influencing the choice of climate variability adaptation and mitigation strategies employed among smallholder maize farmers in Sebayeng village, Limpopo province, South Africa. Primary data were collected from a random sample of 160 smallholder maize farmers through the administration of a structured questionnaire. While descriptive statistics were used to describe and analyse respondents' socioeconomic characteristics; multinomial-logistic regression model was employed to analyse factors influencing farmers' choice of climate variability adaptation and mitigation strategies. Analysis of the data collected showed that the majority of farmers (72.5\%) do not adapt and/or mitigate climate variability. Nonetheless, of those mitigating or adapting to climate variability, $11.9 \%$ of the farmers used shifting planting dates (early planting which runs from October to mid-December) as their strategy because it comes at no cost. Also, about $11.9 \%$ harnessed irrigation facilities, $4.3 \%$ used conservation agriculture and $3.8 \%$ used drought-tolerant varieties. The result of the logistic model revealed that awareness of climate variability, membership of association, occupation and marital status of respondents were found to have a significant influence on the type of adaptation and mitigation strategies chosen by the farmers. The study, therefore, recommends that the government should provide more training for farmers through workshops and seminars to boost their awareness level about climate variability, its adaptation and mitigation. Farmers should also form cooperatives; in that way, they will gain more access to agricultural incentives and they should be encouraged to engage in other economic activities such as processing and marketing of agricultural products to enhance their income.
\end{abstract}

\section{Introduction}

Climate change and variability are rapidly becoming global critical development issues affecting many sectors in the world and are considered to be the most serious threats to sustainable development. In most African countries, crop farming is mainly subsistence and rainfed but due to climate variability which often results in infrequent and untimely rainfall, the harvest of produce and thus, food production is hampered. This makes Africa particularly vulnerable to the impacts of climate variability. The vulnerability of the region is further worsened by the fact that the climate is too hot as it is tropical in nature (Akinnagbe and Irohibe, 2014). It is expected that Africa's agricultural production will be greatly affected by climatic conditions, bearing in mind that the sector is a source of livelihood for many people especially the poor in the rural areas. It has become imperative therefore to protect the livelihood of many farmers to sustain food security (Maddison, 2007).

Farmers in South Africa and Sebayeng village, in particular, are not immune to climate variability patterns which have had a great impact on their livelihood 
trajectories (Maponya et al., 2012). Drought is known to be one of the stumbling blocks to agricultural production, and most of the farmers in Sebayeng village depend on rainfall to grow their crops especially maize. Again, with the literacy level being at the lowest for most of these farmers, maize production in the study area is dominated by the elderly, who depend on indigenous knowledge for agricultural activities (Brown, 2012).

Meanwhile, there continue to be growing interests on the likely impacts of climate variability on agriculture, economic growth and sustainable growth development. This is because Africa has been experiencing increased drought in recent times due to increased temperature and decreased rainfall (Akinnagbe and Irohibe, 2014).

A number of studies have been conducted about the choice of climate variability adaptation, mitigation options and their determinants; but the results were generalised since the studies were undertaken at the national level or macro-level (Tazeze et al., 2012). Population statistics indicated that about $70 \%$ of the world's poor live in rural areas and their main source of livelihood, income and employment is agriculture (Osadebamwen et al., 2015; Oluwatayo, 2019). According to Deressa (2009), some of the factors affecting the choice of adaptation strategy are based on farmers that can afford undertaking soil conservation, plant trees, use crop varieties, changing planting dates, using irrigation to reduce the negative impacts of climate change and variability. Those that did not adapt were affected by the lack of information on adaptation methods and financial constraints. The results of the study indicated that household characteristics such as education, farm and non-farm income have a significant impact on the adaptation of climate change and variability.

While adaptation and mitigation measures help farmers to guard against losses due to increasing temperature and decreasing precipitation (IPCC, 2007), there are various factors determining the farmers' choice of climate variability adaptation and adaptation strategies harnessed. However, for many poor countries that are highly vulnerable, the perception of climate change/ variability by farmers is crucial in designing appropriate adaptation strategy (Tazeze et al., 2012). For some to employ or harness various adaptation and mitigation strategies, it comes at a cost which is one of the factors influencing the type of strategies used by farmers. Therefore, choosing a particular strategy can be linked to various factors that are yet to be discussed or fully understood (Mabe et al., 2014), hence the need for this study.

\section{Methodology}

The study was conducted in Sebayeng village at GaDikgale, which is situated in Polokwane, Limpopo Province, South Africa. The area is $35 \mathrm{~km}$ to the east of the provincial city of Polokwane. Its geographical coordinates are $23.7659 \mathrm{~S}, 29.7004 \mathrm{E}$. The total human population of Sebayeng village is 13,826 people. The number of households in the village is 3279 . The main ethnic group is Sepedi people. Most villagers work as farm labourers on neighbouring farms or as domestic workers in nearby towns and there are some economic activities than just farming that Sebayeng people are engaged in (wage employment) including processing and marketing of agricultural products, tourism, mining, service and self-employment (Mokgokong, 2010). Primary data was used for this study. Systematic random sampling was employed to obtain a representative sample from the smallholder maize farmers with a sample frame of approximately 1657 farmers. However, only a sample size of 160 farmers was used which is above $10 \%$ of the sample frame. This study used an interval of 10 which is a division of sample frame by sample size. A list of Sebayeng farmers was acquired from the local tribal authority and every $10^{\text {th }}$ farmer on the list was selected for further interview, data were collected using a structured questionnaire.

\subsection{Analytical techniques}

Descriptive statistics and Multinomial logistic model were employed as analytical tools. Descriptive statistics entail the use of tools such as tables, graphs, pie charts, histogram, percentages and frequencies to analyse the socio-economic characteristics of smallholder maize farmers at Sebayeng village.

\subsection{Model specification}

Multinomial logistic model (MNL) was used to analyse the second objective. MNL is a model used when the dependent variable is nominal with more than two levels. Thus, it is an extension of logistic regression, which analyses binary dependent variables. MNL model is used to predict categorical placement in or the probability of category membership on a dependent variable based on multiple independent variables. The model allows for more than two categories of the dependent or outcome variable. The model assumes that each independent variable has a single value for each case and the dependent variable cannot be perfectly predicted from the independent variables.

The multinomial logistic model is as follows: 
$Y_{i}=\ln \left(\frac{P_{j}}{P_{1}}\right)=\beta_{0}+\beta_{1} X_{1}+\beta_{2} X_{2}+\beta_{3} X_{3}+\cdots+\beta_{i} X_{i}+\varepsilon_{i}$

$\mathrm{X}_{i}$ where $i=1,2,3 \ldots i$. The independent variable.

$\beta_{i}$ where $i=1,2,3 \ldots i$. The coefficients of the independent variables.

$\beta_{0}=$ The intercept of the model.

$\varepsilon_{i}=$ Disturbance term.

The specific multinomial logistic model

$Y_{i}=\beta_{0}+\beta_{1} S H H+\beta_{2} A G E+\beta_{3} Y O S+\beta_{4} A C X C V I+\beta_{5} H S+\beta_{6} F E+\beta_{7} A C V+\beta_{8} A E S+\beta_{9} A C X C$ $+\beta_{10} O C U+\beta_{11} M A+\beta_{12} M S+\varepsilon_{i}$

Where $Y_{\mathrm{i}}=$ climate variability adaptation and mitigation strategies (no adaptation, drought-tolerant varieties, shifting planting dates, irrigation and conservation agriculture strategies). It should be noted that irrigation strategy was selected as the base category because this is provided by the government of South Africa.

Also, in the selection of factors influencing the choice of adaptation strategies by farmers, a number of factors were considered. According to Nabikolo (2012), in Uganda, there is a gender dimension to choices of climate variability adaptation strategies. The results showed that gender played a role in influencing the choice of adaptation strategies. An important observation from the study was that female-headed households were unlikely to adapt to climate change variability as compared to male-headed households. Shongwe (2014) indicates that households use different adaptation strategies to overcome the negative impacts of climate change and variability. In Swaziland, agricultural production continues to decline as a result of climatic variations, and which is evidenced by an increase in food relief agencies annually. The extent to which these impacts are felt depends on the level of adaptation in response to climate variability. The adaptation strategies included drought-tolerant varieties, switching crops, irrigation, crop rotation, mulching, minimum tillage, early or late planting, intercropping.

The findings of the analysis revealed that the choice of adaptation strategies was significantly influenced by age and occupation of household head, land category, access to credit, being a member of a social group, access to extension services and training, high input prices, high food prices, high incidences of crop pests and diseases, perception of households towards climate change and variability.

Where $X_{1}=$ sex of household head, $X_{2}=$ age of household head, $X_{3}=$ years of schooling for the household head, $X_{4}=$ access to climate variability information, $X_{5}=$ household size, $X_{6}=$ farming experience, $\mathrm{X}_{7}=$ awareness on climate variability, $\mathrm{X}_{8}=$ access to extension services, $\mathrm{X}_{9}=$ access to credit, $\mathrm{X}_{10}=$ occupation of household head, $\mathrm{X}_{11}=$ membership of association, $\mathrm{X}_{12}=$ marital status.

\section{Results and discussion}

\subsection{Socioeconomic characteristics of maize farmers in} Sebayeng village

The results from the descriptive statistics Table 1 show that the minimum age for household head is 29 and the maximum is 93 , while the average age for household head is 62 years. This indicates that most of the household heads in the area are old aged people. From the table it is clear that even the youth in the area are starting to gain interest in farming as the minimum age of the household head indicates that. However, majority of the most interested age group in farming is the elderly with a maximum of 93 years; agriculture is the source of income for most families in the rural areas (Elum et al., 2016).

Table 1. Summary statistics of socioeconomic characteristics (Continuous variables)

\begin{tabular}{cccccc}
\hline Variable name & $\mathrm{N}$ & Minimum Maximum & Mean & Std. \\
\hline Age of household 160 & 29 & 93 & 62.44 & 16.435 \\
$\begin{array}{c}\text { Years of } \\
\text { schooling }\end{array}$ & 160 & 0 & 19 & 6.28 & 5.529 \\
$\begin{array}{c}\text { Farming } \\
\text { experience }\end{array}$ & 160 & 2 & 72 & 25.91 & 16.312 \\
$\begin{array}{c}\text { Household size } \\
\text { Hound }\end{array}$ & 160 & 1 & 13 & 5.39 & 2.513 \\
\hline
\end{tabular}

Education also plays an important role in determining the choice of adaptation and mitigation strategies chosen by farmers, Table 1 shows that there are farmers that did not go to school at all with 0 years (less than a year of schooling), this can be further supported that during the apartheid era, most of our African communities did not have access to education due to colonialism, these resulted in most African population dropping out of schools to go do slavery duties for the whites. However, there are those that managed to pull through and go to school with maximum of 19 years of schooling (Table 1) most of them accumulated tertiary qualification. Average years of schooling are 6 years with a standard deviation of 5.529.

Table 1 also shows that the minimum farming experience that farmers had was a period of 0 year (less than a year of farming experience) and maximum of 72 years. Farmers with an experience of over 65 years are those farmers that have been practising farming from an early age of 14 years or lesser, most started working at farms with their parents at an early age because they did not have the privilege to go to school. On average farmers had farming experience of 26 years and the standard deviation of 16.312 . From the table it is clear 
that farmers at Sebayeng village have been in the farming industry for more than two decades.

Table 1 shows that the minimum family size is 1 , the average family size is 5 and the maximum family size is 13 where the standard deviation is 2.513 . This indicates that in the area there are households with extended members and this is due to high unemployment rate in South Africa so most of the youth migrate to urban areas hoping for greener pastures, so they leave their children at home with their grandparents, this is a trend that has been going for decades.

Majority of the household heads were not mindful of climate variability because most of them did not respond well to climate variability by not mitigating and not adapting to climate variability. This is reflected in Figure 1 where $72.5 \%$ did not mitigate and/or adapt to climate variability; this could be as a result of farmers not having formal education and some do not have any access to climate variability adaptation and mitigation strategies or how to cope and tackle climate variability. However, $11.9 \%$ used shifting planting dates (early planting which runs from October to mid-December) as a mechanism to mitigate climate variability, because it comes at no cost and some of the farmers do not generate any income from production. Only $7.5 \%$ used irrigation as a strategy to adapt to climate variability because some farmers have boreholes; they were able to irrigate their plants and since well they are based in rural areas, they are not charged any fee for using water. About $4.3 \%$ used conservational agriculture, most farmers that used the strategy are those with secondary and tertiary education because the more educated a farmer is, the more receptive they are able to perform through a tailor-made education or with a high formal education attainment. Only $3.8 \%$ used draught-tolerant varieties, as mentioned before that majority of the farmers are elderly people (over 60 years of age) so they are unaware of these strategies, where they can find the draught-tolerant varieties and the literacy level also restricts them from exploring other mitigation and/or adaption strategies for climate variability such as draught-tolerant varieties. The reason for high percentage of farmers at Sebayeng village not adapting and mitigating to climate variability could be due to rural people being reluctant to change hence they end up not coping with these modern methods of farming. Ndamani and Watanabe (2016) showed that dry spells and droughts generally cause wilting and drying up of crop plants. This leads to poor crop development and low yields. Farmers in the study area (Ghana) claimed that socioeconomic effects of climatic change such as out-migration, indebtedness, food shortage and low household incomes can cause psychological trauma.

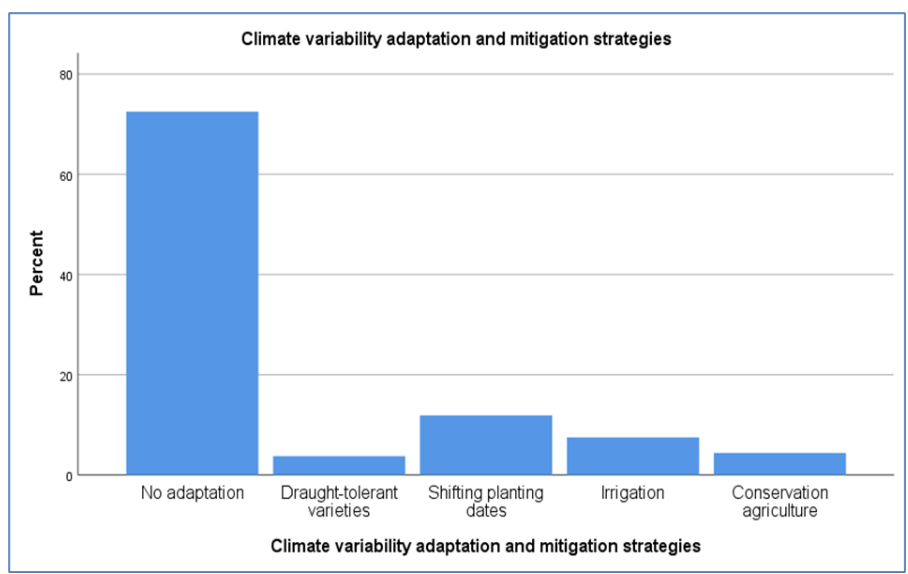

Figure 1. Different climate variability adaptation and mitigation strategies adopted by Sebayeng small-scale maize farmers

Meanwhile, Fadina and Barjolle (2018) disclose that only $14.2 \%$ did not adapt to climatic variation, majority of respondents used improved varieties $(38.3 \%)$, croplivestock diversification (36.7\%) and only a small proportion of the farmers used diversification of income generating activities (14.2\%) as a mitigation strategy. From the findings of previous studies, it should be noted that majority of the farmers adapted to climate variability as compared to Sebayeng maize farmer. The reason for this disparity could be attributed to the different geographical areas, the type of farming practised (some are involved in mixed cropping) and also due to the different socioeconomic characteristics of the farmers. This might be the reason why most Sebayeng maize farmers did not cope well with climate variability.

\subsection{Determinants of climate variability adaptation and mitigation choice}

Tables 3, 4 and 5 below show the multinomial regression results for the factors affecting the choice of climate variability adaptation and mitigation strategies for smallholder maize farmers at Sebayeng village.

\subsection{Factors Influencing the choice of climate variability adaptation and mitigation strategies}

\subsubsection{Marital status of household head}

As indicated in Table 2, there is a negative and significant $(\mathrm{P}<0.05)$ relationship between the marital status of household head and the dependent variable (climate variability adaptation and mitigation strategies No adaption versus Irrigation strategies). Considering irrigation as the base category, farmers that are not married have $-237 \%$ probability of not using any of the climate variability adaptation and mitigation strategies in the study area.

\subsubsection{Membership of association}

The results in Table 2 indicate a positive and significant $(\mathrm{P}<0.05)$ relationship between membership of 
Table 2. Multinomial regression results on determinants of adaptation and mitigation choice (no adaptation versus irrigation strategies)

\begin{tabular}{|c|c|c|c|}
\hline $\begin{array}{c}\text { Climate variability adaptation and mitigation strategies }{ }^{\mathrm{a}} \\
\text { (No Adaptation versus Irrigation strategies) }\end{array}$ & B & Std. Error & Sig. $(P<0.05)$ \\
\hline Intercept & -2.168 & 3.426 & 0.527 \\
\hline Age of the household head & -0.047 & 0.054 & 0.839 \\
\hline Years of schooling (in years) & -0.045 & 0.089 & 0.611 \\
\hline Farming experience (in years) & -0.024 & 0.045 & 0.594 \\
\hline Household size & -0.067 & 0.184 & 0.714 \\
\hline$[$ Sex of the household head $=0]$ & -0.174 & 0.910 & 0.848 \\
\hline No $\quad$ [Access to extension services $=0]$ & 2.834 & 3.443 & 0.41 \\
\hline [Access to credit $=0]$ & -2.056 & 1.614 & 0.203 \\
\hline [Occupation of the household head $=0$ ] & -1.154 & 1.503 & 0.442 \\
\hline [Membership association $=0]$ & 3.031 & 1.092 & 0.006 \\
\hline [Awareness of climate variability $=0$ ] & -27.051 & 1.507 & 0.001 \\
\hline [Access to climate variability information $=0$ ] & -4.77 & 0.007 & 0.004 \\
\hline$[$ Marital status $=0]$ & -2.371 & 1.197 & 0.048 \\
\hline
\end{tabular}

${ }^{\mathrm{a}}$ The reference category is irrigation strategy.

Table 3. Multinomial regression results on determinants of adaptation and mitigation choice (draught-tolerant varieties versus Irrigation strategies)

\begin{tabular}{|c|c|c|c|c|}
\hline \multicolumn{2}{|c|}{$\begin{array}{c}\text { Climate variability adaptation and mitigation strategies } \\
\text { (Draught-tolerant versus Irrigation strategies) }\end{array}$} & $\mathrm{B}$ & Std. Error & Sig. $(\mathrm{P}<0.05)$ \\
\hline \multirow{13}{*}{$\begin{array}{l}\text { Draught- } \\
\text { tolerant }\end{array}$} & Intercept & 0.358 & 2.583 & 0.890 \\
\hline & Age of the household head & 0.005 & 0.038 & 0.902 \\
\hline & Years of schooling (in years) & -0.102 & 0.066 & 0.122 \\
\hline & Farming experience (in years) & -0.029 & 0.031 & 0.357 \\
\hline & Household size & 0.089 & 0.109 & 0.413 \\
\hline & [Sex of the household head $=0]$ & 0.110 & 0.659 & 0.868 \\
\hline & {$[$ Access to extension services $=0]$} & -0.968 & 0.978 & 0.322 \\
\hline & {$[$ Access to credit $=0]$} & 0.192 & 1.048 & 0.854 \\
\hline & [Occupation of the household head $=0]$ & -1.231 & 0.922 & 0.182 \\
\hline & [Membership association $=0]$ & -1.520 & 1.003 & 0.130 \\
\hline & [Awareness of climate variability $=0$ ] & 13.840 & 21.269 & 0.515 \\
\hline & [Access to climate variability information $=0$ ] & -13.456 & 21.278 & 0.527 \\
\hline & {$[$ Marital status $=0]$} & -0.423 & 0.849 & 0.618 \\
\hline
\end{tabular}

${ }^{\mathrm{a}}$ The reference category is irrigation strategy.

Table 4. Multinomial regression results on determinants of adaptation and mitigation choice (shifting planting dates versus Irrigation strategies)

\begin{tabular}{|c|c|c|c|c|}
\hline \multicolumn{2}{|c|}{$\begin{array}{l}\text { Climate variability adaptation and mitigation strategies }^{\mathrm{a}} \\
\text { (Shifting planting dates versus Irrigation strategies) }\end{array}$} & B & Std. Error & Sig. $(\mathrm{P}<0.05)$ \\
\hline \multirow{13}{*}{$\begin{array}{c}\text { Shifting } \\
\text { planting } \\
\text { dates }\end{array}$} & Intercept & 2.168 & 3.426 & 0.527 \\
\hline & Age of the household head & -0.047 & 0.054 & 0.386 \\
\hline & Years of schooling (in years) & -0.087 & 0.082 & 0.289 \\
\hline & Farming experience (in years) & 0.031 & 0.050 & 0.527 \\
\hline & Household size & -0.137 & 0.175 & 0.434 \\
\hline & [Sex of the household head $=0]$ & 0.611 & 0.877 & 0.486 \\
\hline & {$[$ Access to extension services $=0]$} & -0.617 & 1.071 & 0.564 \\
\hline & {$[$ Access to credit $=0]$} & 0.662 & 1.227 & 0.589 \\
\hline & [Occupation of the household head=0] & 0.731 & 1.118 & 0.513 \\
\hline & {$[$ Membership association $=0]$} & -3.031 & 1.092 & 0.006 \\
\hline & {$[$ Awareness of climate variability $=0]$} & 0.006 & 1.144 & 0.996 \\
\hline & [Access to climate variability information $=0]$ & -0.390 & 0.300 & 0.022 \\
\hline & {$[$ Marital status $=0]$} & 1.038 & 0.996 & 0.297 \\
\hline
\end{tabular}

${ }^{a}$ The reference category is irrigation strategy. 
Table 5. Multinomial regression results on determinants of adaptation and mitigation choice (conservation agriculture versus Irrigation strategies)

\begin{tabular}{|c|c|c|c|c|}
\hline \multicolumn{2}{|c|}{$\begin{array}{l}\text { Climate variability adaptation and mitigation strategies }{ }^{\mathrm{a}} \\
\text { (Conservation agriculture versus Irrigation strategies) }\end{array}$} & B & Std. Error & Sig. $(\mathrm{P}<0.05)$ \\
\hline \multirow{13}{*}{$\begin{array}{c}\text { Conservation } \\
\text { Agriculture }\end{array}$} & Intercept & 5.163 & 5.412 & 0.340 \\
\hline & Age of the household head & -0.102 & 0.072 & 0.158 \\
\hline & Years of schooling (in years) & -0.162 & 0.121 & 0.180 \\
\hline & Farming experience (in years) & 0.004 & 0.056 & 0.940 \\
\hline & Household size & -0.053 & 0.174 & 0.759 \\
\hline & {$[$ Sex of the household head $=0]$} & -0.484 & 1.004 & 0.630 \\
\hline & [Access to extension services $=0$ ] & 0.017 & 2.924 & 0.995 \\
\hline & [Access to credit $=0]$ & -1.983 & 2.686 & 0.460 \\
\hline & [Occupation of the household head $=0$ ] & -3.380 & 1.948 & 0.083 \\
\hline & {$[$ Membership association $=0]$} & -5.427 & 3.279 & 0.098 \\
\hline & [Awareness of climate variability $=0$ ] & -0.006 & 1.144 & 0.996 \\
\hline & [Access to climate variability information $=0]$ & 24.912 & 0.001 & 1.566 \\
\hline & {$[$ Marital status $=0]$} & -2.435 & 2.173 & 0.262 \\
\hline
\end{tabular}

${ }^{\mathrm{a}}$ The reference category is irrigation strategy.

association and the dependent variable (climate variability adaptation and mitigation strategies - No adaptation and Irrigation strategies). Considering irrigation as base category, farmers belonging to an association have a $303 \%$ probability of not adopting any of the climate variability adaptation and mitigation strategies in the study area. Similarly, farmers that are not members of association versus those that are members of the association have $-542 \%$ probability of not using conservation agriculture compared with irrigation strategy to mitigate or adapt to climate variability. This implies that being a member of association increases the possibility of a farmer to adapt because farmers' association such as cooperatives provide information on farming, credits and resources that can be used when adjusting to climate variability. Farmers' association also provides support and build relationships amongst farmers to enhance productivity. Menike et al. (2015) discovered that being a member of a society is also important in choosing certain adaptation methods and the probability of adapting to climate change is $62 \%$.

\subsubsection{Occupation of household head}

The results in Table 5 indicate a negative and significant $(\mathrm{P}<0.05)$ relationship between occupation of household head and the dependent variable (climate variability adaptation and mitigation strategies Conservation agriculture and Irrigation strategies). Considering irrigation strategies as the base category, farmers that are engaged in non-agricultural activities have $-338 \%$ probability of not using conservation agriculture as an adaptation and mitigation strategy in Sebayeng village. Shongwe (2014) mentioned that when a farmer is fully engaged in farming, he or she will have enough time to explore various adaptation and mitigation strategies and focus all their resources on farming since it is their only source of income.

\subsubsection{Awareness of climate variability}

The results in Table 2 show a negative relationship between awareness of climate variability of household head and dependent variable at a 5\% significance level. Considering irrigation strategies as a base, farmers that are not aware of climate variability have $-270 \%$ probability of not adopting any strategy of climate variability in the study area. Gbetibouo (2009) emphasised that women are more vulnerable to poverty and have less access to education as compared to men in most households in rural areas. This can have a negative impact when adapting and mitigating climate variability as wealth and education are few of some important determinants of climate variability adaptation and mitigation strategies. The findings support what Gbetibouo (2009) emphasised because the majority of the households are females with no education, has proven that lack of education, being passive to economic issues and not being aware of current affairs (including not being aware of climate variability) leads to farmers being vulnerable, and not able to cope or mitigate climate variability.

\subsubsection{Access to climate variability information}

As depicted by the results in Table 2, there is a negative and significant $(\mathrm{P}<0.05)$ relationship between access of climate variability information and dependent variable (climate variability adaptation and mitigation strategies of no adaptation versus Irrigation strategies). Considering irrigation as a base, farmers that have access to climate variability information have $-477 \%$ probability of not adopting any strategy of climate variability in the study area. The results further indicate a negative and 
significant $(\mathrm{P}<0.05)$ relationship between access of climate variability information and dependent variable (climate variability adaptation and mitigation of Shifting planting dates versus Irrigation strategies). Considering irrigation as a base (see Table 4), farmers with climate variability information have $-390 \%$ probability of not using shifting planting dates as a coping mechanism to adapt and mitigate climate variability.

\section{Conclusion}

Farmers have had to adapt and mitigate the conditions imposed by the climate of their region since the inception of agriculture, but recent human-induced climate change and climate variability is throwing them some unexpected curve balls with extreme heat, floods and droughts as some of the direct effects. In addition, there are changes in weed species and distribution, pests and disease pressure, on top of depleted soils and water stress. Fortunately, there are some emerging practices being incorporated into the agricultural production system to make the system more resilient to the changing climate. Many of the practices typically associated with sustainable agriculture can also be helpful in increasing the resilience of the agricultural system to the impact of climatic variability. The world's poor farmers do not have access to improved seeds, fertilizers, irrigation systems and other beneficial technologies as farmers in rich countries do, and no crop insurance either, to protect themselves against losses. Just one stroke of bad fortune (drought, floods for example) is enough for them to tumble deeper into poverty and hunger. Therefore, resource poor farmers are likely to suffer most.

Based on the findings of this study, the following are recommended:

- Government should build capacity of farmers through education and training on improved production methods. This can be done through workshops and seminars where farmers will be taught on climate changes and variability, its effects, and available strategies to cope and adjust. Estimated future weather reports and previous weather reports should be made available at local libraries to enhance adaptation and mitigation capacities of smallholder farmers in rural areas because awareness of climate variability was found to be statistically significant to influencing the farmers' choice of climate variability adaptation and mitigation strategies.

- Farmers should also form cooperatives because through that way, they will gain more access to agricultural resources (information, credit access and more land) since membership of association was found to be statistically significant.

- In terms of policy implications, the identified strategies should be promoted and supported by the government, private entities and non-governmental organisations to improve the adaptation capacity of farmers to climate variability impacts. Policymakers should formulate policies that are suitable or that cater for elderly people in agriculture because they are the most interested age group in agricultural production and seem to cope with climate variability better in the study area.

- Farmers should also engage in other economic activities such as processing and marketing of agricultural products provided farming fails because the study has shown that farmers that engage in nonfarm activities are likely to adapt to climate variability better.

\section{References}

Akinnagbe, O.M and I.J. Irohibe (2014). Agricultural adaptation strategies to climate change impacts in Africa: A Review. Bangladesh Journal of Agricultural Research, 39(3), 407-418. https:// doi.org/10.3329/bjar.v39i3.21984

Brown, L. (2012). Supporting the participation of young people in agriculture and rural development, p. 212271. South Africa: National Youth Development Agency (NYDA).

Deressa, T.T., Hassan, R.M., Ringler, C., Alemu, T. and Yesuf, M. (2009). Determinants of farmers' choice of adaptation methods to climate change in the Nile Basin of Ethiopia. Global Environment Change, 19 (2), 248-263. https://doi.org/10.1016/ j.gloenvcha.2009.01.002

Elum, Z.A., Modise, D.M. and Marr. A. (2016). Farmer's perception of climate variability and responsive strategies in three selected provinces of South Africa. Journal of Climate Risk Management, 16, 246-257. https://doi.org/10.1016/ j.crm.2016.11.001

Fadina, A.M.R. and Barjolle, D. (2018). Farmers' adaption strategies to climate change and their implications in the Zou department of South Benin. Journal of Environmental Systems Science, 5(1), 217. https://doi.org/10.3390/environments5010015

Gbetibouo, G.A. (2009). Understanding Farmer's Perception and Adaptation to Climate Change and Variability: The Case of the Limpopo Basin, p. 1154. Washington, D.C.: IFPRI.

IPCC (Intergovernmental Panel on Climate Change). (2007). Climate variability: The Scientific Basis, p. 9 -23. United Kingdom: Cambridge University Press. 
https://doi.org/10.1017/CBO9780511546013

Mabe, F.N., Sienso, G, and Donkoh, S. (2014). Determinant of choice of climate variability adaptation strategies in Northern Ghana. Research in Applied Economics, 6(4), 75-189. https:// doi.org/10.5296/rae.v6i4.6121

Maddison, D. (2007). The perception of and adaptation to climate change in Africa. Policy Research Working Papers, p. 14-32. World Bank Group. EBook. https://doi.org/10.1596/1813-9450-4308

Maponya, P. and Mpandeni, S. (2012). Climate change and agricultural production in South Africa: Impacts and adaptation option. Journal of Agricultural Science, 4(10), 148 -161. https://doi.org/10.5539/ jas.v4n10p48

Menike, L.M.C.S and Keeragala Arachchi, K.A.G.P. (2016). Adaptation to climate change by smallholder farmer in rural communities: Evidence from Sri Lanka. Journal of Procedia Food Science, 6, 288292. https://doi.org/10.1016/j.profoo.2016.02.057

Mokgokong, M.J. (2010). The effects of gender inequality on rural household livelihoods diversification. A case study of Sebayeng village, Polokwane, Limpopo Province. South Africa: University of Limpopo, MAdmin thesis.

Nabikolo, D., Bashaasha, B., Mangheni, M.N. and Majaliwa, J.G.M. (2012). Determinants of climate change adaptation among male and female headed farm households in Eastern Uganda. African Crop Science Journal, 20(2), 203-212.

Ndamani, F. and Watanabe, T. (2016). Determinants of farmers' adaptation to climate change: A micro level analysis in Ghana. Journal of Economics and Management, 2(6), 782-844.

Oluwatayo, I.B. (2019). Towards Assuring Food Security in South Africa: Smallholder Farmers as Drivers. AIMS Agriculture and Food, 4(2), 485-500. https://doi.org/10.3934/agrfood.2019.2.485

Osadebamwen, A.O., Ideba, E. and Ikheloa, E. (2015). Young people and agricultural employment: Locality and interest factors. Mayfair journal of Agriculture Development in Emerging Economies, 1(1), 122299.

Shongwe, P. (2014). Factors influencing choice of climate change adaptation strategies by households. A case of Mpolonjeni Area Development Programme (ADP) in Swaziland. Journal of Agricultural Studies, 8(4), 190-291.

Tazeze, A., Jemma, H. and Mengistu, K. (2012). Climate change adaptation strategies of smallholder farmers: The case of Babilie District, East Harerghe zone of Oromia regional state of Ethiopia. Journal of
Economics and Sustainable Development, 3(14), 322 -359 . 